\title{
Strengthening College Support Services To Improve Student Transitioning To Careers
}

\author{
William W. Arnold, Pepperdine University, USA
}

\begin{abstract}
The article reviews challenges facing colleges including the need for actions to address new circumstances of educating college students and preparing them for productive roles following graduation. These challenges are balanced by resources colleges are developing to facilitate college-to-career transitioning to first destinations following graduation. In a review of support services offered by colleges the article identifies innovative programs that show potential for improved career support for students. Sources, including surveys of students and employers, published writing by leaders in education, and reported data from colleges, provide a present view of career support functions and suggest patterns of evolution. Colleges are strengthening their support to student's department by department, but programs and activities across-departments need to be integrated to improve services for students. Leveraging synergies among campus support functions improves services to students. The use of student support case managers may eliminate the silos among college support functions. Designing programs around students and bridging gaps among support services can deliver more relevant and timely results. The article introduces the voices of students expressed in an upper division business course Management Theory and Practice. The actual words of students were acquired as byproducts of class assignments and course evaluations. Collecting these indirectly rather that as the focal point of student input lends a candid perspective. The comments interject both students' requests for assistance and their appreciation for the support they received.
\end{abstract}

Keywords: College Career Services; Student Transitioning to Careers; College to Employment; College to Career Transitioning; Student Career Services; College Graduate First Destinations

\section{INTRODUCTION}

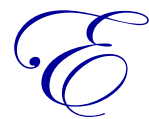

ducational institutions constantly evolve to fulfill their roles in changing times. Periodically the evolutionary pace of progress is disrupted by the need for more extreme, revolutionary change. One extreme example occurred in response to the influx of students following passage of the GI Bill in 1944. Adopting computer capabilities school-wide can be viewed as another. Never before, though, has change been as driven by changes in the students themselves. As millennials make way for Gen-Z students, incoming freshmen increasingly hold expectations of access to advanced software and communication resources. The new generations have been conditioned to having instant access to information and engaging in real time communication on a global scale. They are prone to taking action and are often willing to proceed without the bedrock of theory. It is possible that students, pre-filled with knowledge and exposed to advanced learning opportunities from early ages, have established a learning momentum that is outrunning the rate at which colleges are adapting and changing. In several ways students may be ahead of school deans and faculties assigned to educate them.

In this article we review the forces behind change as well as exemplary innovations by educational institutions, especially in response to students, parents, and employers who need schools to develop students' leadership capabilities and skills that will allow them to be effective in the workforce. Student support functions, typically clustered within a Student Affairs organization, encompass programs that meet student needs for housing, disability services, career services, and other areas of student life. Outside the scope of Student Affairs are significant services provided by academic advisors, campus events, clubs, and programs. Many campus activities offer opportunities for leadership development and skill building for future careers. Student support functions, though, are typically scattered around campuses, and often operate with minimal coordination. As a result support programs that could benefit students may be brought to their attention only sporadically. 
This article includes examples of institutions that have stepped into the future toward service, plus administrative configurations that center on assisting students in their journeys toward careers. Finally the article portrays the need for student support using the voices of students in a Management Theory and Practices course as they are the nearing the reality of finding a career or other destination beyond graduation.

\section{PRESSURES CONFRONTING COLLEGES}

College administrators are reacting to a plethora of factors presently exerting pressure for change. These encompass the need for leadership functions typically inherent in their roles. Top priorities of college deans continue to be budget, faculty recruitment, fundraising, student enrollment, accreditation, faculty development, and internationalization. In addition, changes in school rankings and reputations require attention in an increasingly competitive environment (Association to Advance Collegiate Schools of Business [AACSB], n.d.). Taking a different slant into challenges facing leaders of educational institutions based on a worldwide sample of 31 business schools, D'Alessio and Avolio (2011) found strong faculty, teaching, quality, research programs, facilities, support services, and financial resources to be important. In addition to the accustomed functions of the position, college administrators provide leadership to stakeholders as varied as donors, trustees, alumni, neighboring communities, and federal and local regulators. These continuing pressures are now joined by additional factors that demand deft leadership.

\section{INTENSIFIED INFLUENCES}

All aspects of life, work, and education are subject to changing external factors, and these changes are occurring on a global scale. Educational institutions, as repositories of classical norms, values, and knowledge, have provided building blocks from the past that lead to the future. To place educational institutions within the context of change, it is important to recognize that colleges are not the drivers of change. We can question, however, whether colleges have synchronized with forces in the external environment that account for much of the need for change. Have colleges kept pace? Have they succeeded in meeting needs? Have they adjusted their roles and programs? Are they optimizing their resources to meet the needs of students to master subject matter knowledge? Are they assuring that students have the skills and individual proficiencies they need beyond graduation? Are colleges profoundly and centrally preparing students to find job opportunities or other viable endeavors following graduation?

Ease of mobility, global shrinking, instant communication, gains in science, video sharing, and cultural diversity everywhere have created global connectedness. Enabling capabilities including artificial intelligence, virtual reality, big data, and the abundance of apps are changing the ways we live, work, and interact. Powerful internal and external factors are entangled with traditional and contemporary pressures in forcing change, as shown in Figure 1. 
Figure 1. Factors that influence student support services and readiness to transition to roles following graduation.

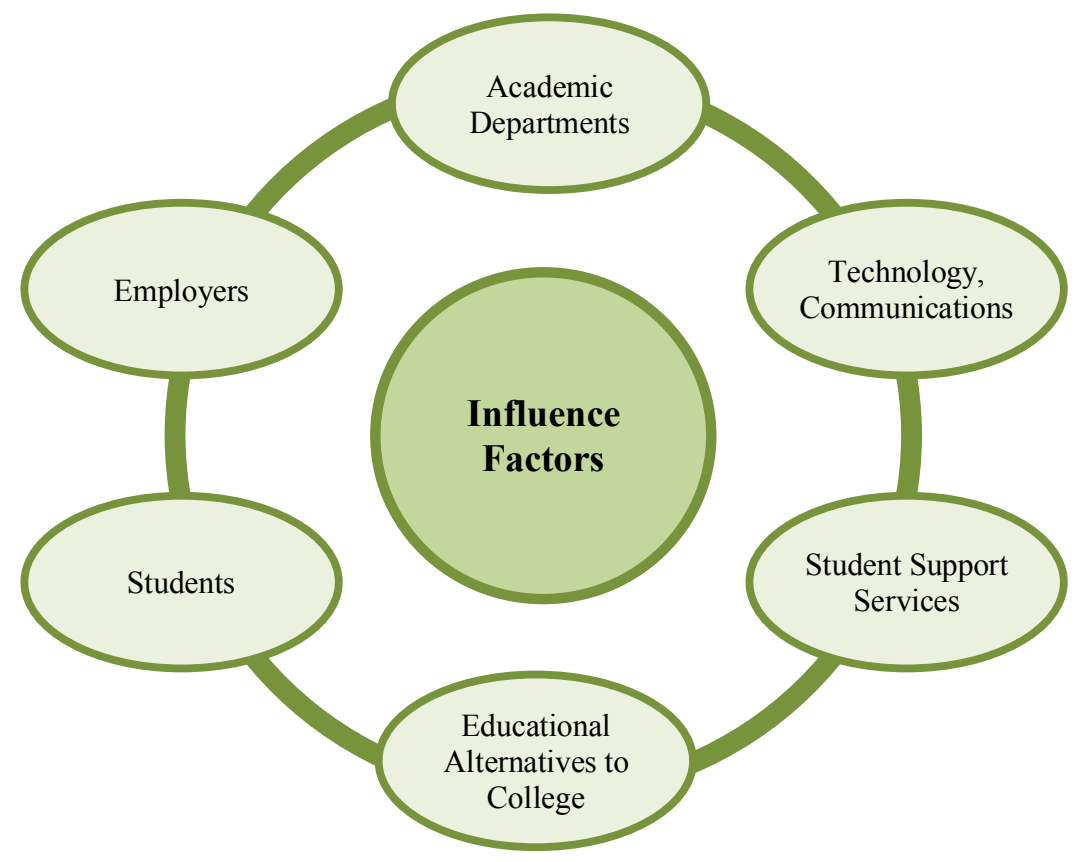

\section{Academic Departments}

Geoffrey Garrett (2016), Dean, The Wharton School, pointed out that business schools are changing both the content of their curriculums and their methods of teaching. Scrutiny of departmental structures, policies, and practices is underway. For example, when tenured faculty members retire, they are more likely to be replaced with part-time or non-tenure-track full-time faculty (Hainline, Gaines, Long Feather, Padilla, \& Terry, 2010). In a Gallup survey of college and university presidents Stubbs (2016) found discrepancies between the professional advancement practices followed in colleges versus the criteria actually practiced. The findings disclosed that decisions concerning promotions conflicted between the path to career success for professors via research and publishing and the relegated importance attributed to faculty members as teachers (Stubbs, 2016).

Decrying the drift that has swung the balance from teaching to scientific research by faculty members as the means of assuring advancement, Bennis and O'Toole (2005) in their article "How Business Schools Lost Their Way" advocated placing more emphasis on improving the competence of graduates and hiring faculties that understand the drivers of business performance. As stated by the authors "The best classroom experiences are those in which professors with broad perspectives and diverse skills analyze cases that have seemingly straightforward technical challenges... and then reveal hidden strategic, economic, competitive, human, and political complexities" (Bennis \& O'Toole, 2005, What Gets Taught section, para. 2).

Changes are occurring across college departments as professors adapt to greater complexity. Raghaven and Ganesh (2015) studied characteristics of effective teachers as in six roles: as a person, classroom manager, instructional organizer, instructional deliverer, and monitor of student progress and potential (Raghaven \& Ganesh, 2015). The authors framed their research around six factors shown to have importance in determining service quality, satisfaction, and retention: administrative support, career placement, academic faculty support, institutional factors, instructional program, and information system support (Raghaven \& Ganesh, 2015).

One of the persistent appeals used by colleges to attract prospective students has been their low student-faculty ratios with the implication that students may have a high degree of interaction with their professors. College administrators, through their marketing strategies and student support staffs, reinforce the claim of caring professorstudent relationships (Chory \& Offstein, 2017). Stubbs (2016) found that professors who demonstrated care and 
concern motivated students to become excited about learning, and having mentors while in school encouraged students to pursue their goals. Further, well-being following graduation along with workplace achievement were linked to having positive undergraduate experiences (Stubbs, 2016). Chory and Offstein (2017) examined pros and cons of close student-professor interactions. On the minus side the authors noted cases of professors feeling uncomfortable about being involved in their students' personal dilemmas and lives. When-and-how issues related to setting boundaries in the social distance between faculty members and students are often not addressed, and many faculty lack training in providing emotional support and offering advice for personal issues. Contrary to expectations students may prefer an arms-length experience with their professors that is focused on coursework and grades (Chory \& Offstein, 2017).

\section{Employers}

Students are coming into their college experiences with perspectives that began forming in their preschool years. As students enter college at 18 to 20 years of age, their lived experience represents a very short window for understanding the path of change that earlier generations have experienced. Employers, responding to competitive pressures in the marketplace, are in flux as they make continual changes in their requirements for new hires. In favor of college educations, employment is rising faster in occupations requiring more preparation (Pew Research Center, 2016). "The number of workers in occupations requiring average to above-average education, training and experience increased from 49 million in 1980 to 83 million in 2015, or by 68\%" (Pew Research Center, 2016, p. 3).

Roos (2014) noted that goals for educating leaders need to include understanding of sustainable global thinking, entrepreneurship, innovation, and decision making based on "practical wisdom" (Roos, 2014, p. 1). Calling for a renaissance in business education, Roos advocated for training that prepares graduates to deal with the complex problems facing companies that will employ them. Also emphasized by Roos is the need to teach students to make decisions based on outcomes that will benefit the global community.

How do employers perceive the preparation of college graduates? Based on the Job Outlook 2016 Survey by NACE (National Association of Colleges and Employers, 2016a) of 19 attributes of college graduates most valued by employers the highest ranking were leadership (80.1\%); ability to work in a team (78.95\%); communication skills, written (70.2\%); problem-solving skills (70.2\%); communication skills, verbal (68.9\%); and strong work ethic (68.9\%). Findings from surveys conducted of employers and college students by Hart Research Associates (2015) on behalf of the Association of American Colleges \& Universities compared learning outcomes employers expect and preparation students perceive they have gained prior to entering the workforce. Learning outcomes employers rated as most important were written and oral communication skills, teamwork skills, ethical decision-making, critical thinking, and the ability to apply knowledge in real-world settings (Hart Research Associates, 2015). College graduates, though, fell short of employers' expectations on all of the 17 outcomes employers rated as important. By contrast, college students felt their colleges had prepared them well in 11 of the 17 factors tested (Hart Research Associates, 2015). Whereas $80 \%$ of employers indicated it is very important that college job applicants demonstrate the ability to apply learning in real-world settings, only $14 \%$ of employers thought most college students are prepared with the skills and knowledge needed to complete a significant applied learning project (Hart Research Associates, 2015).

Hodges and Burchell (2003) compared students' perceptions of their performance readiness on 25 work-related competencies with employers' perceptions of students' on-the-job performance. Employers also rated the importance they associated with the same competencies. The most valued competency by employers, according to Hodges and Burchell (2003), was ability and willingness to learn. That is, in the face of change employers felt employees must be willing to learn new skills, and they need to be perceived as possessing high potential to acquire knowledge. Competencies that impact an organization's performance including customer service, quality, accuracy, interpersonal communication, and problem solving ranked high in importance. In addition, qualities such as drive, passion, motivation, and internal attitudes contribute to a prospective graduate's employability. As stated by Hodges and Burchell (2003), "employers want 'well-rounded' graduates with a broad range of competencies" (p. 19). 


\section{Students}

Students, also, are buffeted from several sides. The increasingly demanding requirements by prospective employers are compounded by the financial squeeze involving rising costs and relatively stagnant incomes. Parents are pressured to conserve their spending due to the 2008-2009 economic downturn that undercut financial assets available to pay college tuitions. Parental limitations add to the incentives for students to seek education that prepares them to earn a paycheck (Hanover Research, 2014).

Students can readily identify with individuals who did not complete college, such as Bill Gates of Microsoft and Mark Zuckerberg of Facebook, yet succeeded beyond far beyond early expectations. According to Brown (2016) Americans are questioning the need for a college degree, with a mere $16 \%$ of U.S. adults indicating that a bachelor's degree prepares students "very well" for careers. As new generations enter the workforce, expectations and values, as well as students' priorities and agendas for the future, are also changing.

How satisfied with their educations are students? Although a consensus of factors can be reduced to a relatively confined set, it is also evident that standardization of data collection could produce clearer insights. In a study of 1,202 college business seniors Letcher and Neves (2010) focused on factors that have the greatest impact on students. The criteria of satisfaction the authors applied were meeting of expectations, value of the educational investment, and likelihood of recommending the program to a friend. Factors carrying the greatest weights were extra-curricular activities, career opportunities, and quality of teaching. Among factors Maddox and Nicholson (2008) found that accounted for student satisfaction were school environment, quality of advising, and computer resources including student support services. The school environment covered interpersonal dynamics and perceptions of feeling valued by faculty as evidenced by faculty members demonstrating availability outside the classroom and interest in helping the students. In a review of attributes that most influence student satisfaction with their educational experience, Gibson (2010) found quality of teaching, skills and knowledge acquired, and the curriculum to be most significant. Non-academic factors that figured significantly were feelings of belonging, and perceptions of institutional responsiveness and concern (Gibson, 2010).

\section{Technology, Communications}

College administrations are transitioning to adopt more efficient methods as they apply technologies that assist with the performance of functions, operations, and communications institution-wide. In addition, data can be mined in new ways to produce valuable insights related to student needs and the effectiveness of programs. The ubiquitous presence of communication capabilities and the ability to connect programs previously operated as islands are allowing colleges to deliver choices to the campus community and to allow students to interact and benefit from more institutional resources.

Especially as Generation Z, born in 1995 and later, is now joining the Baby Boomers, Generation X, Millennials (Generation Y), the sustained adoption of the technology in all areas of education and work is unmistakable (Accounting Principals, 2016). "Today's students have very sophisticated expectations for the way technology facilitates their campus experience" (Contomanolis, Cruzvergara, Dey, \& Steinfeld, 2015, Technology section, para. $1)$.

Are colleges keeping up? Courses in digital or online subjects such as business analytics, as Ozgur, Li, and Rogers (2015) found, can be handicapped by lack of fundamental resources including data sets, case examples, adequate choice of textbooks, software tools, and technical support capabilities. As employees in the workforce and recent graduates recognize the need to continually update their knowledge and skills, technology advances in artificial intelligence, augmented reality, simulation techniques, and related capabilities will become increasingly prevalent in classrooms and workplaces (Rainie \& Anderson, 2017).

An indication that colleges are welcoming management expertise around using computer technologies to assist learning was the appointment in 2015 of Daniel Schwartz to the position of Dean of the Stanford University Graduate School of Education (Lapin, 2015). Schwartz's previous position had been overseeing a laboratory at Stanford that develops teaching and learning technologies. 


\section{Career Support Services}

Three critical junctures in the education-to-employee progress were identified in a study of 8,000 education providers, youth, and employers across nine countries conducted by The McKinsey Center for Government to gain insights into issues in education to employment: (a) enrolling in postsecondary education, (b) building job-relevant sills, and (c) finding a job. College career services can have a role in meeting these challenges extending from college matriculation through graduation (Mourshed, Farrell, \& Barton, 2012).

Addressing demands placed on college career services, Philabaum (2015) discussed changes being forced by state legislatures, the federal government, media, parents, students, and alumni in the interest of improving students' transition from school to gainful employment. Philabaum referenced two roadblocks to career services effectiveness: (1) getting students into the career center and (b) receiving sufficient resources to perform the career services functions effectively.

Colleges have shifted from earlier access-related priorities to their current emphasis on student success initiatives according to Coley, C., Coley, T., and Lynch-Holmes (2016), senior consultants with the software portfolio and services provider Ellucian. Success measures include persistence to graduation, transfer success, time to degree, and improved learning outcomes. Colleges, the authors assert, now "bear responsibility for providing students with the support the need to achieve their goals" (Coley et al., 2016, p. 1). A comprehensive review of opportunities for college students to build skills outside the classroom was offered by Bob Franek (2017), Editor-in-Chief at the Princeton Review. Among these programs are alternating work with courses (cooperative education), job-shadowing programs, internships, research, community service, student organization activities, study abroad, and independent projects involving special interests from theater to lab volunteering (Franek, 2017).

Higher levels of accountability around student outcomes are being demanded even by accrediting agencies as observed by Coley et al. (2016). Standardization of student education outcomes has aided comparability among educational institutions. In the report First Destinations for the College Class of 2015 (NACE, 2016b), destination categories include standard employment, entrepreneur, contract employee, freelance, internship, service, and military, plus continuing education. The summary presentation used by the Kenan-Flagler Business School at the University of North Carolina, (Vogel, 2016) shows student outcomes by industry, business discipline, full time, internship, graduate study, geographic region, top destination cities, and compensation, including signing bonus (Vogler, 2016).

The focus of future career services will include building connections through partnerships and developing career communities of learners and networks that engage students and alumni. A theme that ties career services together is placing students' employability at the center of all campus communities (Dey \& Cruzvergara, 2017).

Delta State University has established a student success center with committees covering academic advising, early alert, first-year seminar, and institutional data analysis. Student success efforts enlist the academic council, the dean council, academic leaders, and freshmen orientation and enrollment groups (Coley et al., 2016). Mercy College in New York City developed a Personalized Achievement Contract (PACT) with students. As part of the program mentors are cross-trained in academic advising, financial aid, student support services, and are actively engaged with students from pre-enrollment through all steps in the students experience (Coley et al., 2016). In a more encompassing scope a student success center may train faculty, frontline staff, residence hall directors, and other staff who serve as a first line response to student questions and concerns "For many students, knowing that someone in the institution cares about how they are performing is a powerful motivator" (Coley et al., 2016, p. 5).

The changing structural relationships within support functions and the added impetus given to student success in transitioning at Leigh University is evident in the creation of a new position at the Associate Dean level within the College of Business and Economics. This position was designed to strengthen programing, events, and services offered to business students (Lehigh University College of Business and Economics, 2017a), and in coordination with the university-wide Center for Career and Professional Development Office. As stated, an intention was to provide professional development opportunities that prepare students to be effective in leadership roles in organizations (Lehigh University College of Business and Economics, 2017a). 
Specifically, the position was designed to:

- Solidify commitment to support for transitioning

- Enhance students' skills for professional success

- Encourage leadership development opportunities

- Prepare students for business situations in the U.S. and abroad

- Provide career-related skills development

- Increase technology usage

- Assess outcomes

\section{Educational Alternatives to College}

While colleges have carried the lead role in fulfilling post high school education needs, they are now adapting within an environment populated with additional viable educational alternatives. In the midst of changes underway on college campuses, a new industry has gained traction in delivering education and training for college age students and employees in mid-career and beyond. Public opinion about responsibility for preparing workers for employment with the right skills is divided with individuals carrying the heaviest weight, at $75 \%$; $\mathrm{K}-12$ educational institutions at 60\%; colleges and universities at 52\%; and employers at 49\% (Pew Research Center, 2016).

Along with possibilities created by technology, new methods have emerged to deliver educational content. Free online learning can be accessed in a variety of forms ranging from YouTube videos to formal online courses. The rise of massive open online courses (MOOCs), delivered digitally, allows college students to fulfill a portion of their credit hours if the institution accepts these credits (The Economist, 2014). Free educational options are a boon for students at a time when costs associated with a college education have risen to become prohibitive for many. Flatter salary increases make it harder to justify the higher costs of a college education (The Economist, 2014).

The emphasis by employers is on jobs that require higher levels of social skills, analytic abilities (including critical thinking), and proficiency with technology (Pew Research Center, 2016). Jobs that require physical or manual skills, earn at lower rates, whereas the pay advantage of higher skilled jobs is growing (Pew Research Center, 2016). New competitors including consulting firms are moving into the education space. For example, consultants have added services to update executives who need to know about big data, social media, and mobile technology (Turpin, 2015). More than half of working adults indicate that it will be necessary for them to acquire new skills and training throughout their careers. (Pew Research Center, 2016).

Competency-based education and training customized around student career interests has emerged as an educational innovation that rivals college degree programs. This approach tends to appeal to adult, nontraditional students (Fain, 2016) and may include opportunities to obtain job-related certificates and licenses. A pilot program at Purdue University is transdisciplinary, allowing students to cross departmental lines to acquire the skills needed to meet their goals.

Competency frameworks, even with traditional courses, may be designed from the end-point, a career objective. Some programs include competency assessments integrated into courses or allow bypassing courses. Other programs redesign curriculum around projects or modules, and still others build in options for independent student work in which the student progresses through the program at their chosen pace. The focus shifts from credit hours completed to a more efficient model that eliminates redundant coursework that may not be relevant to the student's goal (Klein-Collins, 2012).

\section{THE TRAJECTORY OF EDUCATIONAL SCENARIOS}

Driven by the momentum to change, including becoming more focused on improving students' career prospects, colleges are revising curriculums, adding courses to cover emerging disciplines, encouraging cross-department relationships, and exploring innovative uses of technologies (Lorange, Sheth, \& Thomas, 2014). 


\section{Shifts in Academic Subjects and Delivery}

Academic departments are implementing structural changes such as bringing into faculties more specialists and practitioners. Colleges are using more part-time faculty and even sharing faculty across institutions (Lorange et al. 2014). The educational focus in the future, according to Garrett (2016), will embrace experiential learning outside the classroom, place emphasis on entrepreneurship and innovation, and develop skills of leadership and ability to use data analytics toolkits. Undergraduates are being encouraged to become discoverers rather than passive receivers of knowledge. (Hainline et al. 2010). The changing forces are affecting how faculty teach and how students learn. "The traditional teaching methodologies...are becoming obsolete in a world that encourages people to think critically and creatively" (Hainline et al. 2010, p. 1).

In the interest of improving the success of students in meeting their post-college goals a large roster of possibilities spans all stages from conceptual to trial and full implementation. The following list suggests approaches that are likely to be integrated into future educational programs (Contomanolis et al. 2015; Hainline et al. 2010; Hanover Research, 2014; Lorange et al. 2014).

- Interactive learning

- Experiential learning

- Team learning

- Service learning

- Online courses (MOOCS)

- Industry expert input
- Competency-based programs

- Games, simulations

- Independent projects

- College-to-career curriculum

- Career fairs

- Online interviewing

\section{Employer Partnering}

Earn and learn programs are being adopted that give students a preview of the world their education is preparing them to enter (Lorange et al., 2014). More robust programs involving work-study and internships will require close collaboration with employers (Hainline et al., 2010). Changes will benefit employers as well as students. Companies that invested in in-house training and apprenticeship programs with universities retained $90 \%$ of their new hires after one year and $73 \%$ stayed more than five years, a retention rate $10 \%$ or more higher than experienced with students who had no internship or co-op program involvement (Hanover Research, 2014). The following possibilities for employer partnering were have been suggested (Hanover Research, 2014; Hainline et al., 2010; Lorange et al., 2014):

- Earn and learn programs

- Internships

- Apprenticeships

- Mentorships

- Student employment
- Cooperative education

- Work-based learning

- Alumni career coaches

- Volunteer jobs

- Shadowing opportunities

In an article that covers benefits and pitfalls of alumni and employer mentoring programs Pfeifer (2002) emphasized the importance to students of checking in with their academic advisor. The advisor may provide moderating views about new directions suggested by the mentor, and students may find their mentor helpful in refining their career plans, which may have implications for the student's academic program.

\section{Innovative Programs}

Lehigh University's College of Business and Economics (2017b) offers specialized support to students at different points in their academic progress. Each student is assigned an advisor before arriving on campus. A professional advisor supports each student through the four years and connects students to resources and support systems offered at the University. Automated appointment scheduling and advertised walk-in hours add to convenience for students. During their first year students maintain regular contact with their peer mentor. Following declaration of major students are assigned a faculty mentor. Mentors, advisors, and career counselors work as a team that focuses on 
optimizing the student's experience and supporting successful transitioning following graduation (Coley et al., 2016).

Using employers as curriculum designers was found among innovative approaches attempted by colleges. More activities are becoming available for employers to work with students from the outset of college entrance and throughout students' educational experience. At the analytical and administrative levels, system integrators, or team leaders, can be effective in working with educators and employers to find solutions, gather data, and identify new possibilities (Mourshed et al., 2012). Other solutions involved technology facilitated standardized curriculum, perhaps supplemented with employer-specific content, and game simulation (Mourshed et al., 2012).

\section{Support and Collaboration}

Collaborative relationships will be needed among alumni relations, fundraising, development, admissions, academic advisers, faculty and staff, researchers, department heads, academic administrators, student service organizations, student employment, community service organizations, student clubs, institutional research, and institutional assessment and planning (Contomanolis et al., 2015). Hints for innovative ideas may be found in the practices followed in other countries. In India, for example, employers reach out to parents to influence choice of major study areas (Capelli, 2015). The following listing indicates the comprehensiveness of activities that touch students and, potentially, can become part of the equation for student success (Capelli, 2015; Contomanolis et al., 2015; Day \& Cruzvergara, 2017):

- Administrations

- Academic departments

- Faculty

- Staff

- Student Affairs

- Career Services

- Learning Centers
- Technology Support

- Alumni affairs

- Development, fundraising Research centers

- Customized networking

- Advisory boards
- Admissions

- Academic advisors

- Student organizations

- Parents, families

- Employers

- Professional Associations

Predicting trends in student support services Dey and Cruzvergara (2017) indicated that "All signs point to an integrated model of customized connections and communities that extends the responsibility of college employability...to an ecosystem that fully engages the entire university network of students, alumni, faculty, employers, families, and surrounding communities" (Dey \& Cruzvergara, 2017, p. 1). The authors predict that "Customized connections and self-sufficient communities will be the new way.... and new assessments will measure reputation, engagement, and destination outcomes, along with coordinated campus partnerships (Dey \& Cruzvergara, 2017).

\section{A PERSPECTIVE FROM STUDENTS}

Pepperdine University is a private, religious-affiliated educational institution with undergraduate enrollment of over 3,500 students plus graduate student enrolled in five graduate schools including law and business. Pepperdine ranks in the top 50 of Best Colleges among National Universities by U.S. News \& World Report (2017). In addition to the Malibu, California campus of 860 acres, which overlooks the Pacific Ocean, Pepperdine offers study abroad programs at its U.S. and international campuses.

The university offers choices of 41 undergraduate majors and 38 minors. Student-professor interaction is encouraged by the low student-faculty ratio of 14 to 1 and class sizes of fewer than 20 students in $69 \%$ of its classes. The university typically achieves a retention rate of $77 \%$ from entry through graduation. A first-destination survey of Pepperdine University graduates six months following completion of degrees showed $89 \%$ employed, admitted to graduate school, engaged in full-time volunteering, or pursuing graduate school plans. 
The Seaver College, Business Division offers Bachelor of Science degrees in Accounting, Business Administration, and International Business. Management Theory and Practice, BA 352, is an upper division course. The course description from the Seaver Catalog (Pepperdine University, 2017) is:

A study of the basic concepts of management built on an understanding of organizational theory. Equal emphasis is placed on theoretical and operational aspects of the manager's role in organizations. The course deals with management issues: planning and controlling, structuring and staffing, directing and leading and business and society with a special emphasis on managerial ethics. Prerequisite: ENG 101 or equivalent (p. 136).

The course is described as a lecture class. The 18 students in the class met on campus at 8:00 to 9:45 on Tuesdays and Thursdays for a total of 16 class sessions. The assigned text was Understanding Management, by Richard Daft and Dorothy Marcic (2015). The Professor supplemented the class text with articles and notes. The professor received the Howard A. White Award for Teaching Excellence in 2014, an honor determined by university-wide student vote.

\section{Class Composition}

In close alignment with Pepperdine University demographics, women students in the class constituted the majority with $60 \%$; approximately $12 \%$ were international students who received their high school educations outside the United States. By academic standing the class was composed of 9 seniors, 6 juniors, and 3 sophomores. Appendix Table A1 shows detail of the class composition. Academic majors represented were:

- Advertising

- Economics

- Journalism

- Marketing
- $\quad$ Marketing Communications

- Media Production

- Music (Applied Music)

- Pre-Business Administration
- Pre-International Business

- Psychology/Organization Psych

- Public Relations

- Sport Administration

\section{METHODOLOGY}

Actual student comments provided the basis for drawing insights into the topics that resonated with students. The intention of this approach was to explore whether a difference could be detected between the stated purpose of the course and the content that captured students' attention and showed potential to make a lasting difference in their lives and careers. Student comments were collected as a byproduct of class assignments and therefore provided a rich set of "glimpse over the shoulder" revelations. The methodology was selected to avoid the sometimes-expected questions and surface responses of the survey approach.

\section{VOICES OF THE STUDENTS}

\section{What Management Means to Me: Summary of Comments from Student Papers at Beginning and End of Course}

At the beginning of the course students were requested to complete a written statement in response to the question "What does management mean to me? This request was repeated at the end of the course. Most students responded that they continued to hold most of the ideas expressed at the beginning of the course, but amended their responses at the end of the course to add new insights. Appendix Table A2 shows specific comments student by student. Their comments are summarized in Table 1, following: 
Table 1. Comparison of Emphasis: Selected Comments, Beginning and End of Course

\begin{tabular}{|c|c|c|}
\hline Factor & Beginning of Course & End of Course Additions \\
\hline Leadership & $\begin{array}{l}\text { - Lead by example } \\
\text { - Be the mastermind. Understand the } \\
\text { organization }\end{array}$ & $\begin{array}{l}\text { - React to any situation } \\
\text { - Serve, influence, and perform }\end{array}$ \\
\hline $\begin{array}{l}\text { Self-awareness, self- } \\
\text { management }\end{array}$ & $\begin{array}{l}\text { - Self-aware leader } \\
\text { - Manage ourselves, self-control }\end{array}$ & $\begin{array}{l}\text { - Be self-aware; understand myself, understand } \\
\text { others } \\
\text { - Leaders know themselves } \\
\text { - High emotional intelligence } \\
\text { - I look at the way I mange people much } \\
\text { differently now }\end{array}$ \\
\hline Power, control, effort & $\begin{array}{l}\text { - Work hard. Push through tough times } \\
\text { - Overcome barriers to success } \\
\text { - Make tough decisions. Face consequences } \\
\text { - Be in charge; management means control } \\
\text { - Do things the right way } \\
\text { - Operate smoothly with few or no errors } \\
\text { - Work ethic; keep everything functioning } \\
\text { - Standard of employees keeping each other } \\
\text { - Improve others' weaknesses } \\
\text { - Balance financial performance with a thriving } \\
\text { - culture } \\
\text { - Keep the organization focused and on track } \\
\text { - Opsure productivity and performance }\end{array}$ & $\begin{array}{l}\text { - Control and reflection. How factors affect } \\
\text { performance } \\
\text { - Do what you say. Take responsibility }\end{array}$ \\
\hline $\begin{array}{l}\text { Interaction, } \\
\text { relationships }\end{array}$ & $\begin{array}{l}\text { - Build team cohesion and trust } \\
\text { - Nurture culture that motivates others } \\
\text { - Empower by emphasizing talents } \\
\text { - View self as part of the team } \\
\text { - Bring diverse groups of people together } \\
\text { - Challenge while encouraging } \\
\text { - Know that their success is your success } \\
\text { - Be hands-on and involved } \\
\text { - Connect with employees, treat with respect } \\
\text { - Be open in relationships } \\
\text { - Treat as employees, not just numbers } \\
\text { - Work toward common goals }\end{array}$ & $\begin{array}{l}\text { - Be both business and people oriented } \\
\text { - Pay close attention to needs of people } \\
\text { - Give employees freedom and trust } \\
\text { - Allow employees to fulfill familial and } \\
\text { personal needs } \\
\text { - Help others achieve success } \\
\text { - Always take time for people } \\
\text { - Maintain solid relationships with employees } \\
\text { - Work alongside employees and be part of the } \\
\text { - team }\end{array}$ \\
\hline Receptivity, service & $\begin{array}{l}\text { - Serve rather than dictate } \\
\text { - Be selfless and put others first }\end{array}$ & $\begin{array}{l}\text { - Know there are many ways to make decisions } \\
\text { - Be open; see all perspectives } \\
\text { - Consider opinions and ideas } \\
\text { - Use input from all to reach best decision } \\
\text { - Support others to motivate them } \\
\text { - Serve people placed in your life } \\
\text { - Serve including doing the dirty work } \\
\text { - Use signs and symbols to define and articulate } \\
\text { - goals } \\
\text { - Do not operate and make decisions by alone } \\
\text { - Put employees above yourself }\end{array}$ \\
\hline Other & $\begin{array}{l}\text { - Communicate effectively } \\
\text { - Motivate and inform employees } \\
\text { - Embody ethics and values }\end{array}$ & $\begin{array}{l}\text { - Now I know more and on a deeper level } \\
\text { - Have an open door }\end{array}$ \\
\hline
\end{tabular}

Source: Based on student papers, Management Theory and Practice, Seaver College Business Division, Pepperdine University 
The topics students expressed in responding to the question "What does management mean to me?" at the beginning and end points of the course were compared to the topics covered in the course textbook. The assigned course text, at more than 600 pages, provides comprehensive coverage of management subjects. The five parts of the textbook and the associated chapters are listed in Table 2.

Table 2. Major Topics of the Course Textbook

\begin{tabular}{|c|c|c|c|c|}
\hline $\begin{array}{c}\text { Introduction to } \\
\text { Management (Part I) }\end{array}$ & $\begin{array}{l}\text { Planning } \\
\text { (Part II) }\end{array}$ & $\begin{array}{c}\text { Organizing } \\
\text { (Part III) }\end{array}$ & $\begin{array}{l}\text { Leading } \\
\text { (Part IV) }\end{array}$ & $\begin{array}{c}\text { Controlling } \\
\text { (Part V) }\end{array}$ \\
\hline $\begin{array}{l}\text { 1. Management } \\
\text { 2. The History of } \\
\text { Management } \\
\text { 3. Organizational } \\
\text { Environments and } \\
\text { Cultures } \\
\text { 4. Ethics and Social } \\
\text { Responsibility }\end{array}$ & $\begin{array}{l}\text { 5. Planning and } \\
\text { Decision Making } \\
\text { 6. Organizational } \\
\text { Strategy } \\
\text { 7. Innovation and } \\
\text { Change } \\
\text { 8. Global Management }\end{array}$ & $\begin{array}{l}\text { 9. Designing Adaptive } \\
\text { Organizations } \\
\text { 10. Managing Teams } \\
\text { 11. Managing Human } \\
\text { Resource Systems } \\
\text { 12. Managing } \\
\text { Individuals and a } \\
\text { Diverse Work Force }\end{array}$ & $\begin{array}{l}\text { 13. Motivation } \\
\text { 14. Leadership } \\
\text { 15. Managing } \\
\text { Communication }\end{array}$ & $\begin{array}{l}\text { 16. Control } \\
\text { 17. Managing } \\
\text { Information }\end{array}$ \\
\hline
\end{tabular}

Source: Daft and Marcic, 2015

Although the textbook provided the primary subject matter for the course, students extracted from the text, readings, and class experience those portions most meaningful and relevant to them. The comments by students show a shift from relatively stereotypical views of management to more internalized, people-sensitive, and personal views that also included elements of service. Comments related to management power and control at the beginning of the course were neutralized by comments at the end of the course that suggest students were looking toward being open with employees and interacting with them, as well as being earning trust, and being receptive to new ideas.

\section{Immediate Learnings from Class Sessions and Changes in Views of Management}

As a means of capturing key points that "hit home" with students during class, students were provided with $3 \times 5$ " cards at 11 class meetings and were requested to write responses to the statements "What I learned in today's class" and "How my view of management changed." A summary of students' comments is presented in Table 3. 
Table 3. Highlights from Student Comments: "What I Learned in Today's Class" and "How My View of Management Changed"

\begin{tabular}{|c|c|c|}
\hline Class Session & \multicolumn{2}{|c|}{ Comment Highlights } \\
\hline 1 & $\begin{array}{l}\text { - Human resource importance; importance of } \\
\text { human capital } \\
\text { - Human resources attracts candidates, then } \\
\text { advocates for employees }\end{array}$ & $\begin{array}{l}\text { - Decisions based on diversity of input are better } \\
\text { - Diverse workforce produces better results }\end{array}$ \\
\hline 2 & $\begin{array}{l}\text { - Managers must understand themselves; be self- } \\
\text { aware }\end{array}$ & - Listen to people to understand their perceptions \\
\hline 3 & $\begin{array}{l}\text { - Set personal priorities } \\
\text { - Gain in emotional intelligence } \\
\text { - Important to manage stress }\end{array}$ & $\begin{array}{l}\text { - Self-knowledge is key } \\
\text { - Personality and emotions are important }\end{array}$ \\
\hline 4 & $\begin{array}{l}\text { - Managers versus leaders; they are different } \\
\text { - Humility is an asset } \\
\text { - Leaders emphasize service } \\
\text { - Difference between power and influence }\end{array}$ & $\begin{array}{l}\text { - Authenticity counts } \\
\text { - Be accountable, true to self } \\
\text { - Focus on people, goals, influence } \\
\text { - Ethics and emotional intelligence are important }\end{array}$ \\
\hline 5 & $\begin{array}{l}\text { - Purpose } \\
\text { - Collaboration } \\
\text { - Intrinsic motivation } \\
\text { - Focus on strengths }\end{array}$ & $\begin{array}{l}\text { - Trust from those led } \\
\text { - Difference between leaders and managers } \\
\text { - Know own strengths }\end{array}$ \\
\hline 6 & $\begin{array}{l}\text { - Know who you are } \\
\text { - Overcome obstacles } \\
\text { - Create your own reality } \\
\text { - Be motivated }\end{array}$ & $\begin{array}{l}\text { - Intrinsic motivation } \\
\text { - Adapt and learn } \\
\text { - See failure as opportunity to grow } \\
\text { - Effort to achieve. Persist }\end{array}$ \\
\hline 7 & $\begin{array}{l}\text { - Drive (motivation) is required to be successful } \\
\text { - Motivation is intrinsic. It must come from within } \\
\text { - Need for passion } \\
\text { - Open business model. }\end{array}$ & $\begin{array}{l}\text { - Autonomy needed } \\
\text { - Self-management importance } \\
\text { - Managers must be motivated themselves }\end{array}$ \\
\hline 8 & $\begin{array}{l}\text { - Expectations influence motivation, performance } \\
\text { - Needs hierarchy as tool } \\
\text { - Energy generates passion } \\
\text { - Perception of being treated fairly }\end{array}$ & $\begin{array}{l}\text { - Listen to learn what motivates people. Understand } \\
\text { their needs } \\
\text { - Equal treatment of employees } \\
\text { - Motivate by setting challenging goals, }\end{array}$ \\
\hline 9 & $\begin{array}{l}\text { - Communication; open channels } \\
\text { - Honest, direct, and clear communication } \\
\text { - Cross-functional and collaborative activities } \\
\text { - Purpose-directed communication }\end{array}$ & $\begin{array}{l}\text { - Influence through communication } \\
\text { - Make certain that information is understood } \\
\text { - Communication leads to improve effectiveness } \\
\text { - Be candid in communications }\end{array}$ \\
\hline 10 & $\begin{array}{l}\text { - Teams } \\
\text { - Management success depends on teams } \\
\text { - Managers need to guide teams } \\
\text { - Independence not willingly given up } \\
\text { - Manager assures ownership for efficient team } \\
\text { functions } \\
\text { - Teams need trusting relationships }\end{array}$ & $\begin{array}{l}\text { - Need to articulate clear direction } \\
\text { - Accountability and commitment important } \\
\text { - Address conflict } \\
\text { - Teams lead to more creativity } \\
\text { - Specific goals must be set }\end{array}$ \\
\hline 11 & $\begin{array}{l}\text { - Ethics drives behavior } \\
\text { - All parts are connected to the whole } \\
\text { - Operating structure needs to be fluid } \\
\text { - Importance of shared goals }\end{array}$ & $\begin{array}{l}\text { - Align goals, communication, and other aspects } \\
\text { - All factors of an organization are intricately linked }\end{array}$ \\
\hline
\end{tabular}

Source: Student comments from 3x5 cards completed at 11 class sessions, Management Theory and Practice, Seaver College Business Division, Pepperdine University

Similar to the points evident in the contrast between "What management means to me at the beginning and end of the course, students expressed views that were decidedly people-sensitive and personal. The comments on the $3 \times 5$ " cards appeared to be in the character of "notes to self," or "How I will conduct myself as a manager." Students clearly acknowledged the need to know one's strengths and become more self-aware. Also emphasized was the importance of relating to self and others, as well as emphasis on development of soft skills to strengthen interactions with others, communication capabilities, and teamwork. 


\section{Final Papers}

Students were instructed to prepare a final term paper that focused on five academic topics of personal and professional interest. A major purpose was to connect academic learning with practical applications. Each student selected a high performing organization related to their career interests and preparation. Length of the paper was specified to be 10 pages plus references. The five themes each student selected to focus on for the final paper were entered into a spreadsheet with each row representing a student's choices. The descriptive words and phrases students used were then analyzed to identify the essence of each theme. The resulting terms and phrases were then alphabetized and grouped to identify the five predominant themes for the class as a whole. Appendix Table A3 shows the results of the analysis, which is summarized in the following Table 4.

Table 4. Topics Students Selected as Themes for Final Term Paper

\begin{tabular}{|c|c|c|c|c|}
\hline \multirow{2}{*}{$\begin{array}{l}\text { Topic Group } \\
\text { Human elements }\end{array}$} & \multicolumn{4}{|c|}{ Terms and Phrases Used Related to Topic Group } \\
\hline & $\begin{array}{l}\text { - Human resources } \\
\text { - People } \\
\text { - Culture } \\
\text { - Employees }\end{array}$ & $\begin{array}{l}\text { - Human capital } \\
\text { - Motivation (talent) } \\
\text { - People first } \\
\text { - Personal growth }\end{array}$ & $\begin{array}{l}\text { - Recruiting } \\
\text { - Teams } \\
\text { - Team trust }\end{array}$ & $\begin{array}{l}\text { - Teamwork } \\
\text { - Training } \\
\text { - Workplace } \\
\text { effectiveness }\end{array}$ \\
\hline $\begin{array}{l}\text { Management, mission, and } \\
\text { strategy }\end{array}$ & $\begin{array}{l}\text { - Accomplishments } \\
\text { - Accountability } \\
\text { - Adaptability } \\
\text { - Commitment }\end{array}$ & $\begin{array}{l}\text { - Decision making } \\
\text { - Leadership } \\
\text { - Management style } \\
\text { - Mission }\end{array}$ & $\begin{array}{l}\text { - Organization } \\
\text { - Organization } \\
\text { structure } \\
\text { - Responsibilities } \\
\text { - Results }\end{array}$ & $\begin{array}{l}\text { - Risks } \\
\text { - Servant leadership } \\
\text { - Strategic } \\
\text { management } \\
\text { - Strategic planning }\end{array}$ \\
\hline Technology related & - Technology & - Innovation & - Communication & $\bullet$ \\
\hline Social responsibility: & $\begin{array}{l}\text { - Diversity } \\
\text { - Environment }\end{array}$ & $\begin{array}{l}\text { - Ethical culture } \\
\text { - Social } \\
\text { responsibility }\end{array}$ & $\begin{array}{l}\text { - Values } \\
\text { - Whistle blowing }\end{array}$ & - Women \\
\hline Globalization & - Globalization & & & \\
\hline
\end{tabular}

Based on a comparison of similarities and differences between the course textbook topics and student themes, two topics evidenced a higher share of interest than would have been surmised from the text topic chapters alone. The two highest interest themes were (a) the human elements and (b) technology, innovation, and communication. The technology interest coincided with several students choosing technology companies for their employment interest and reflects a concentration of technology companies in California.

\section{Course Evaluations}

At the end of each semester the Business Division of Seaver College, Pepperdine University, conducts a survey of students in each class. Responses are confidential and not attributed to any specific student. The survey covers general questions about the course organization, conduct of the course, grading fairness, the overall class experience, and students' perceptions of the professor. In response to question 7, "the course is excellent," students' rating was 4.58 on a 5 point scale. Scores on the 14 rating questions are shown in Table 5. 
Table 5. Student Evaluations of Course: Management Theory \& Practice, Spring 2017

\begin{tabular}{l|c}
\hline Ratings of the Course. The Course: & $\begin{array}{c}\text { Mean Student Ratings } \\
(\mathbf{1 - 5 , 5} \text { High) }\end{array}$ \\
\hline $\begin{array}{l}\text { 1. Is well organized } \\
\text { 2. Textbook and other reading assignments are appropriate in content }\end{array}$ & 4.44 \\
\hline 3. Tests and other evaluations are appropriate in content and difficulty & 4.53 \\
\hline 4. Assignments are reasonable and appropriate in content and difficulty & 4.58 \\
\hline 5. Is demanding in comparison to other courses & 3.95 \\
\hline 6. Has increased my knowledge or understanding of the subject & 4.68 \\
\hline 7. Is excellent & 4.58 \\
\hline 8. Has enhanced my ability to think clearly, logically, independently, and critically & 4.53 \\
\hline 9. Has contributed to the development of my sense of personal values and moral integrity & 4.61 \\
\hline Ratings of the Professor. The Professor: & 4.84 \\
\hline 1. Shows interest and enthusiasm for teaching the course & 4.84 \\
\hline 2. Is available outside of class for consultation if needed & 4.68 \\
\hline 3. Is prepared for class and makes good use of class time & 4.68 \\
\hline 4. Is an excellent teacher & 4.32 \\
\hline 5. Presents course material in a clear and engaging manner & \\
\hline Sour Seave Colege Busing Divion, Peppon
\end{tabular}

Source: Seaver College Business Division, Pepperdine University, Student Evaluation Survey Results

\section{Comments by Students to the Pepperdine University Evaluation Survey}

\section{Evidence of Benefits Beyond the Curriculum}

- The wisdom, advice, and mentorship that came out of it!

- The professor was the best professor, friend, and mentor I've ever had at Pepperdine.

- I want to apply what we talk about to my life...It is making me a better person.

- I have learned so much about organizational management that I think can be applied not only to an organization and how it functions, but also material that is applicable to life.

- It has opened up my way of thinking about how to approach a situation, people, and groups of people in general.

- It helped me learn to interview and communicate with others. It has prepared me to launch into the next chapter after college.

- [The professor] has shown the value of being ethical despite what obstacle may come your way.

\section{Appreciation of Caring for Students}

- I have talked to [my professor] multiple times a week for career help. He is always available and is absolutely amazing at navigating students to the next phase of life.

- He has set office hours, but also gives you his personal cell to contact if you need to get a hold of him. I have contacted him on multiple occasions and he always answers.

- He even gave us his business card! And always tells us he is available and there for us even outside of class. What an incredible thing for a teacher to say!

- He always offers to meet outside of class and offers to help us no matter what.

- He effortlessly weaves the academic with the real world application.

- He has a lot of wisdom and experience.

- Best teacher I have had at Pepperdine.

- Absolutely! He goes above and beyond and is more than a teacher! He is a mentor to me.

- His goal is to help make us better people.

- He genuinely cares for his students.

- He sees past the student and cares about the person.

- He is wise, has great advice, is approachable, is available and puts his students first. 


\section{CONCLUSION}

New initiatives and programs are being implemented by colleges to strengthen assistance to students as they transition to new roles following graduation. Changes being made in response to demands from parents whose financial flexibility is constrained, from employers whose competitive pressures are reshaping job requirements for employees, and from the proliferation of technologies that offer new methods of operating, communicating, and delivering educational curriculums.

Published sources were reviewed to identify the present status of support to students in transition to endeavors following graduation. The literature also revealed issues of student support, trends, and examples that foreshadow changes being made in colleges to support student transitioning. Data in several forms supplied by students enrolled in a business management course at a liberal arts college were analyzed. The findings indicated student interest in the subject matter, as stated in the course description and assigned textbook, diverged from the subjects that predominated in capturing students' interests. Students also reported significantly benefiting from the attention given during class sessions and outside the classroom by a professor who listened, counseled, and advocated for students.

\section{New Approaches to Address Changing Needs}

Combining the review of published sources and student data, the following programs and changes represent approaches that are moving into place and becoming established in colleges to meet students' preparation for careers and life following college:

- A course organized to develop soft skills in teamwork communication, self-awareness, selfmanagement, and problem solving in the context of completing simulated work projects. Best practices would also be covered related to speech, writing, oral presentation, assertiveness, conflict resolution, appearance, hygiene, and workplace protocols.

- Work programs tied to employers, including internships, apprenticeships, earn and learn opportunities, shadowing, and mentorships.

- Standardized online and self-paced classes that cover basic fields of knowledge, including massive open online courses (MOOCS).

- Campus communication networks (24/7 and real time) that focus on interests or needs communities that cross academic departments, advisors, student affairs, career services, campus life, and other touch points related to students.

- The capability to coordinate and track support activities that assist students in their performance and progress toward completing college and transitioning into their roles following graduation.

- Lessening of barriers caused by needless formalities that cut off access by students to resources and information.

\section{Upended Priorities and a Way Forward}

Colleges face pressures from several directions as they change in ways that strengthen support for students. Two changes in perception may be needed in resetting priorities:

- Colleges need to prioritize and implement policies, initiatives, curriculum delivery, and support programs that ensure high rates of student success. Adopting a student success priority for some colleges may mean turning upside down an outdated perception of the college as an institution that processes students in accordance with long-held traditions in favor of new ways that align with an altered environment and new standards of excellence. 
- Colleges need to hear the voices of students. Colleges need to learn to listen, hear, and carefully consider student input from multiple contexts. Making changes for colleges, along with associated complexity, conflicting priorities, and hard decisions about allocation of resources, can be a daunting challenge for colleges. How refreshing to simplify the complexity by listening to students and being guided toward change by the messages their voices carry.

\section{AUTHOR BIOGRAPHY}

William W. Arnold is a Professor in the Business Division of Seaver College, Pepperdine University, Malibu, California where he teaches Management Theory and Practice, Current Issues in Management, Business Strategy, and Servant Leadership. Dr. Arnold held executive positions with several major health systems where he led revitalization and turnaround. A champion of authenticity in leadership, Dr. Arnold presented his experiences in The Human Touch. In engaging with students he illustrates business principles by drawing on examples from his career. Dr. Arnold holds Doctor's, Master's, and Bachelor's degrees, respectively, from Pepperdine University; University of California, Los Angeles; and the University of Washington.

\section{REFERENCES}

Accounting Principals (2016). Generation optimization: Strategies for recruiting, retaining, and inspiring a multigenerational workforce. Retrieved rom https:/www.accountingprincipals.com/employers/employer-resources/generationoptimization/

Association to Advance Collegiate Schools of Business (AACSB) (n.d.). AACSB 2014-2015 deans survey. Retrieved from http://www.aacsb.edu/-/media/aacsb/docs/research/data\%20downloads/deans-survey-infographic-2014.ashx?la=en

Bennis, W., \& O’Toole, J. (2005). How business schools lost their way. Harvard Business Review. Retrieved from https://hbr.org/2005/05/how-business-schools-lost-their-way

Brown, A. (2016). Key findings about the American workforce and the changing job market. Pew Research Center. Retrieved from http://www.pewresearch.org/fact-tank/2016/10/06/key-findings-about-the-american-workforce-and-the-changingjob-market/

Capelli, P. (2015). How colleges — and employers — fail to prepare students for work. Knowledge@Wharton [online network]. Retrieved from http://knowledge.wharton.upenn.edu/article/why-recent-grads-arent-prepared-for-work/

Chory, R. M., \& Offstein, E. H. (2017). Your professor will know you as a person: Evaluating and rethinking the relational boundaries between faculty and students. Journal of Management Education, 4(1).

Coley, C., Coley, T., \& Lynch-Holmes, K. (2016). Retention and student success: Implementing strategies that make a difference. Ellucian [White paper series]. Retrieved from http://www.ellucian.com/White-Papers /Retention-andstudent-success/

Contomanolis, E., Cruzvergara, C., Dey, F., \& Steinfeld, T. (2015). The future of career services is now. NACE Journal. Retrieved from http://www.naceweb.org/career-development/trends-and-predictions/the-future-of-career-services-isnow/

Daft, R. L., \& Marcic, D. (2015). Understanding Management ( $9^{\text {th }}$ ed.). Stamford, CT: Cengage Learning.

D’Alessio, F. A., \& Avolio, B. (2011). Business schools and resources constraints: A task for deans or magicians? Research in Higher Education Journal, 13. Retrieved from www.aabri.com/manuscripts/11912.pdf

Dey, F., \& Cruzvergara, C. (2017). 10 future trends in college career services. Career Services Institute (CSI). Retrieved from https://www.csiwest.org/blog/2017/04/10/10-future-trends-in-college-career-services/

The Economist. (2014). The future of universities: The digital degree. Retrieve from https://www.economist.com/news/briefing/21605899-staid-higher-education-business-about-experience-welcomeearthquake-digital

Fain, P. (2016). Competency for the traditional-age student. Inside Higher Ed (Website). Retrieved from https://www.insidehighered.com/search/site/Competency $\% 20 \% 2 \mathrm{~B} \% 20$ for $\% 20 \% 2 \mathrm{~B} \% 20$ the $\% 20 \% 2 \mathrm{~B} \% 20$ traditionalage $\% 20 \% 2 \mathrm{~B} \% 20$ student

Franek, R. (2017). 10 ways to build job skills while you're in college. The Princeton Review. Retrieved from https://www.princetonreview.com/college-advice/experiential-learning-opportunities

Garrett, G. (2016). How business education will look in the future. Retrieved from https://www.linkedin.com/pulse/howbusiness-education-look-future-geoffrey-garrett

Gibson, A. (2010). Measuring business student satisfaction: A review and summary of the major predictors. Journal of Higher Education Policy and Management, 32(3), 251-259. http://dx.doi.org/10.1080/13600801003743349

Hainline, L., Gaines, M., Long Feather, C., Padilla, E., \& Terry, E. (2010). Changing students, faculty, and institutions in the twenty-first century. Peer Review, 12(3). Retrieved from https://www.aacu.org/publicationsresearch/periodicals/chaing-students-faculty-and-institutions-twenty-first-century 
Hanover Research. (2014). $21^{\text {st }}$ century recruiting and placement strategies. Retrieved from http://www.hanoverresearch.com/media/21st-Century-Recruiting-and-Placement-Strategies.pdf

Hart Research Associates. (2015). Falling short? College learning and career success. Retrieved from https://www.aacu.org/sites/default/files/files/LEAP/2015employerstudentsurvey.pdf

Hodges, D., \& Burchell, N. (2003). Business graduate competencies: Employers' views on importance and performance. Asia Pacific Journal of Cooperative Education, 4(2), 16-22. Retrieved from www.apjce.org/files/APJCE_04_2_16_22.pdf

Klein-Collins, R. (2012). Competency-based degree programs in the U.S.: Postsecondary credentials for measurable student learning and performance. Council for Adult and Experiential Learning (CAEL). Available from www.cael.org

Lapin, L. (2015). Professor Daniel Schwartz to lead Stanford Graduate School of Education. Stanford News [Online]. Retrieved from http://news.stanford.edu/2015/07/08/new-education-dean-070815/

Lehigh University College of Business and Economics. (2017a). Associate Director of CBE Undergraduate Programs [Position description]. Lehigh University. Retrieved from https://lehigh.hiretouch.com/positiondetails?jobID $=42000 \&$ job $=$ associate-director

Lehigh University College of Business and Economics. (2017b). Student advising. Lehigh University. Retrieved from https://cbe.lehigh.edu/academics/undergraduate/student-advising

Letcher, D. W., \& Neves, J. S. (2010). Determinants of undergraduate business student satisfaction. Research in Higher Education Journal. Retrieved from http://www.aabri.com/manuscripts/09391.pdf

Lorange, P., Sheth, J. N., \& Thomas, H. (2014). New models and the changing contexts of business school. The European Business Review. Retrieved from http://www.europeanbusinessreview.com/newbusiness/models/and/the/changing/contexts/of/business/school-2/

Maddox, E. N., \& Nicholson, C. Y. (2008). The business student satisfaction inventory (BSSI): Development and validation of a global measure of student satisfaction. Developments in Business Simulation and Experiential Learning, 35, 101-112. Retrieved from https://journals.tdl.org/absel/index.php/absel/article /view/393

Mourshed, M., Farrell, D., \& Barton, D. (2012). Education to employment: Designing a system that works. McKinsey Center for Government. Retrieved from https://mckinseyonsociety.com/downloads/reports /Education/Education toEmployment_FINAL.pdf

National Association of Colleges and Employers [NACE]. (2016a). Job outlook 2016: The attributes employers want to see on new college graduates' resumes. Retrieved from http://www.naceweb.org/career-development/trends-andpredictions/job-outlook-2016-attributes-employers-want-to-see-on-new-college-grad

National Association of Colleges and Employers [NACE]. (2016b). First destinations for the college class of 2015. Retrieved from https://www.naceweb.org/uploadedfiles/pages/surveys/first-destination/nace-first-destination-survey-executivesummary.pdf

Ozgur, C., Li, Y., \& Rogers, G. (2015). Trends in selecting undergraduate business majors and international enrollment and expected salaries. Journal of Education and Learning, 4(3). Doi:10.5539/jel.v4n3p45

Pepperdine University. (2017). Pepperdine Seaver College of Letters, Arts, and Sciences 2017-2018 Academic Catalog, p. 136. Retrieved from https://seaver.pepperdine.edu/academics/content/2017seavercatalog.pdf

Pew Research Center. (2016). The state of American jobs: How the shifting economic landscape is reshaping work and society and affecting the way people think about the skills and training they need to get ahead. Retrieved from http://www.pewsocialtrends.org/2016/10/06/the-state-of-american-jobs/

Pfeifer, S. E. (2002). The benefits of establishing a student/alumni mentoring program. The Mentor: An Academic Advising Journal. Retrieved from https://dus.psu.edu/mentor/old/articles/021007sp.htm

Philabaum, D. (2015). Talk is in the air-career services must change. Careerstrategy.com [Blog]. Retrieved from http://careercenterstrategy.com/talk-is-in-the-air-career-services-must-change/

Raghavan, S., \& Ganesh, R. (2015). Addressing service quality to increase students' satisfaction and retention in Malaysian private higher education institutions. American Journal of Economics, 5(2): 243-250. DOI: 10.5923/d.economics:201501.31

Rainie, L., \& Anderson, J. (2017). The future of jobs and jobs training. Pew Research Center. Retrieved from http://www.pewinternet.org/2017/05/03/the-future-of-jobs-and-jobs-training/

Roos, J. (2014). The renaissance we need in business education. Harvard Business Review. Retrieved from https://hbr.org/2014/07/the-renaissance-we-need-in-business-education

Stubbs, H. (2016). Restoring University faculty's role of teaching and student service. Gallup News [Online]. Retrieved from http://news.gallup.com/opinion/gallup/195569/restoring-university-faculty-role-teaching-student-service.aspx

Turpin, D. (2015). Top 5 qualities of the best business professors. IMD Business School. Retrieved from https://www.linkedin.com/pulse/top-5-qualities-best-business-professors-dominique-turpin/

U. S. News \& World Report. (2017). Best colleges/Pepperdine University. https://www.usnews.com/best-colleges/pepperdineuniversity-1264

Vogel, D. (2016). Undergraduate business 2015-2016 student outcome statistics. University of North Carolina. Retrieved from http://www.kenan-flagler.unc.edu/ /media/files/documents/bsba_outcomes_one_pager_2015_2016.pdf?la=en 


\section{APPENDIX}

Table A1. Composition of Class Members

\begin{tabular}{l|l|c}
\hline Name (pseudonym) & \multicolumn{1}{c}{ Major } & Level \\
\hline Roger & Media Production & Senior \\
\hline Marvin & Sport Administration & Sophomore \\
\hline Jasmine & Integrated Marketing Communications & Junior \\
\hline Lisa & Sport Administration & Junior \\
\hline Albert & Sport Administration & Senior \\
\hline Roslyn & Public Relations & Senior \\
\hline Karen & Music (Applied Music), Marketing (Non-Business Major) & Senior \\
\hline Oscar & Economics/Marketing (Non-Business Major) & Senior \\
\hline June & Advertising, Industrial/Org Psychology & Senior \\
\hline Nathan & Sport Administration & Junior \\
\hline Helene & Public Relations & Senior \\
\hline Steven & Journalism & Senior \\
\hline Gregory & Pre-International Business & Sophomore \\
\hline Robert & Pre-International Business & Sophomore \\
\hline Jordyn & Sport Administration & Junior \\
\hline Raphael & Economics, Pre-Business Administration & Junior \\
\hline Henry & Sport Administration & Junior \\
\hline Marla & Psychology, Industrial/Org Psychology & Senior \\
\hline Source Pepper
\end{tabular}

Source: Pepperdine University student records 
Table A2. What Management Means to Me: Additions and Changes to Perceptions Offered at Course Beginning

\begin{tabular}{|c|c|c|}
\hline Name & $\begin{array}{c}\text { Student Descriptions } \\
\text { Beginning of Course, } 1 / 27 / 17\end{array}$ & $\begin{array}{l}\text { Changes and Additions } \\
\text { End of Course, 3/15/17 }\end{array}$ \\
\hline Roger & $\begin{array}{l}\text { Lead by example. Work Hard. Do things the right way. } \\
\text { Team cohesion and trust. Work Ethic. Love for what } \\
\text { you do. Show effort. }\end{array}$ & $\begin{array}{l}\text { Understand myself. Understand others. } \\
\text { Lead by example. Know there are many } \\
\text { ways to make decisions. }\end{array}$ \\
\hline Marvin & $\begin{array}{l}\text { Teamwork and unity. Strong culture. Culture that } \\
\text { motivates others. Push through tough times. } \\
\text { Management is key to success and efficiency of an } \\
\text { organization. }\end{array}$ & $\begin{array}{l}\text { Be open. Vulnerability and support } \\
\text { motivates others. }\end{array}$ \\
\hline Jasmine & $\begin{array}{l}\text { Self-aware leader. Empower all members by } \\
\text { emphasizing their talents. Improve others' weaknesses. } \\
\text { Effective communicator. Overcome barriers to success. } \\
\text { View self as part of the team. }\end{array}$ & $\begin{array}{l}\text { Both business and people oriented. Pay } \\
\text { close attention to needs of people. Give } \\
\text { employees freedom and trust. Allow } \\
\text { fulfilling familial and personal needs. }\end{array}$ \\
\hline Albert & $\begin{array}{l}\text { Bring diverse groups of people together. Serve rather } \\
\text { than dictate. Make tough decisions. Face consequences } \\
\text { of decisions. }\end{array}$ & $\begin{array}{l}\text { Help others achieve success. Always take } \\
\text { time for people. }\end{array}$ \\
\hline Roslyn & $\begin{array}{l}\text { Be selfless and put others first. Communicate. Challenge } \\
\text { while encouraging. Mutual relationship: their success is } \\
\text { your success. }\end{array}$ & $\begin{array}{l}\text { Leaders know themselves. Self-aware. High } \\
\text { emotional intelligence. (I look at the way I } \\
\text { manage people much differently now.) }\end{array}$ \\
\hline Karen & $\begin{array}{l}\text { Management means control. Total understanding of } \\
\text { organization. Be the mastermind. Keep everything } \\
\text { functioning. }\end{array}$ & $\begin{array}{l}\text { Control and reflection. How factors affect } \\
\text { performance. }\end{array}$ \\
\hline Oscar & $\begin{array}{l}\text { Lead and take initiative, even when difficult. Manage } \\
\text { ourselves. Self-control. Work with other people. }\end{array}$ & Serve people placed in my life. \\
\hline Nathan & $\begin{array}{l}\text { Lead in the company. Be hands-on and involved. } \\
\text { Connect with employees. Improve relationships with } \\
\text { everyone they supervise. }\end{array}$ & $\begin{array}{l}\text { React to any situation. Maintain solid } \\
\text { relationships with employees. }\end{array}$ \\
\hline Helene & $\begin{array}{l}\text { Balance financial performance, while creating an } \\
\text { environment for the team to thrive. Create a place where } \\
\text { employees feel comfortable and keep each other } \\
\text { accountable. }\end{array}$ & $\begin{array}{l}\text { Serve, influence, perform. Serve: including } \\
\text { doing the dirty work. Influence: Use signs } \\
\text { and symbols to define and articulate visions } \\
\text { and goals. Perform: Do what you say; take } \\
\text { responsibility. Work alongside employees } \\
\text { and be part of the team. }\end{array}$ \\
\hline Steven & $\begin{array}{l}\text { Relationships between boss and people beneath them. } \\
\text { Open style in relationships. Treat as employees, not just } \\
\text { numbers. Leadership allows the people to do amazing } \\
\text { things. }\end{array}$ & $\begin{array}{l}\text { Management needs enthusiastic employees. } \\
\text { Managers can make people into zealots for } \\
\text { the company. }\end{array}$ \\
\hline Gregory & $\begin{array}{l}\text { Keep an organization focused and on track. Promote } \\
\text { core values of the organization. Support employees as } \\
\text { driving factor. Motivate and inform employees. Work } \\
\text { towards common goals. Embody ethics and values. } \\
\text { Assure productivity and performance. }\end{array}$ & $\begin{array}{l}\text { Now know more and on a deeper level. } \\
\text { Managers do not operate and make } \\
\text { decisions by themselves. Best to use input } \\
\text { from all to reach best decision. }\end{array}$ \\
\hline Raphael & $\begin{array}{l}\text { Fulfill goals and ideas. Operate smoothly and fluidly } \\
\text { with few or no errors. }\end{array}$ & $\begin{array}{l}\text { Fulfill goals and ideas about a company, but } \\
\text { also others. Employees provide a positive } \\
\text { work ethic. }\end{array}$ \\
\hline Henry & $\begin{array}{l}\text { Be in charge of daily operations. Supervise employees. } \\
\text { Treat employees with respect. }\end{array}$ & $\begin{array}{l}\text { Have an open door and put employees } \\
\text { above yourself as key to being a successful } \\
\text { manager. }\end{array}$ \\
\hline Marla & $\begin{array}{l}\text { Professional and personal management. Professional: } \\
\text { Production, skills and operating efficiency with results. } \\
\text { Personal: Employees and their satisfaction. Strong } \\
\text { development of personal management and involvement. }\end{array}$ & $\begin{array}{l}\text { See all perspectives. Consider opinions and } \\
\text { ideas. }\end{array}$ \\
\hline
\end{tabular}


Table A3. Final Paper: Themes Selected as Preferred Characteristics of a Company as a Prospective Employer

\begin{tabular}{|c|c|c|c|c|c|}
\hline $\begin{array}{l}\text { Student } \\
\text { Name }\end{array}$ & Theme 1 & Theme 2 & Theme 3 & Theme 4 & Theme 5 \\
\hline Roger & Innovation & Risks & Culture, People & Adaptation & Global \\
\hline Marvin & Mission & Programs, Client & Accomplishments & Responsibilities & Organization, Staff \\
\hline Jasmine & Mission & Culture, Values & Diversity & Management Style & Teams \\
\hline Albert & Motivation & Team & Technology & Globalization & Diversity \\
\hline Roslyn & Human Resources & Management & Teamwork & Innovation & Critical Thinking \\
\hline Karen & Innovation & Culture & Adaptation & Global & Strategic Planning \\
\hline Oscar & Human Capital & Culture & Training & Personal Growth & Communications \\
\hline June & Ethical culture & Innovation & Global & Motivation & Values \\
\hline Nathan & $\begin{array}{l}\text { Technology, } \\
\text { Communictn }\end{array}$ & Human Resources & Women & Diversity & Ethics \\
\hline Helene & Innovation & Culture & Teams & Employees & Diversity \\
\hline Steven & Motivation & Innovation & Culture & $\begin{array}{l}\text { Social } \\
\text { Responsibility }\end{array}$ & Decision Making \\
\hline Cara & Diversity & $\begin{array}{l}\text { External } \\
\text { Environmt. }\end{array}$ & $\begin{array}{l}\text { Innovation, } \\
\text { Adapting }\end{array}$ & Leadership & Strategy \\
\hline Gregory & Globalization & Diversity & Innovation & Human Resources & $\begin{array}{l}\text { Technology, } \\
\text { Communictn }\end{array}$ \\
\hline Robert & Leadership & Organization & People First & Culture & Communication \\
\hline Raphael & Human Resources & Environment & Culture & $\begin{array}{l}\text { Strategic } \\
\text { Management }\end{array}$ & $\begin{array}{l}\text { Workplace } \\
\text { Effectiveness }\end{array}$ \\
\hline Henry & Culture & Mission & $\begin{array}{l}\text { Social } \\
\text { Responsibility }\end{array}$ & Whistle Blowing & Recruiting \\
\hline Brandon & Team Trust & Productive Conflict & Commitment & Accountability & Results \\
\hline Marla & $\begin{array}{l}\text { Organization } \\
\text { Structure }\end{array}$ & Servant Leadership & $\begin{array}{l}\text { Social } \\
\text { Responsibility }\end{array}$ & Motivation & Human Resources \\
\hline
\end{tabular}

Source: Student final term papers, Management Theory and Practice, Seaver College Business Division, Pepperdine University 
NOTES 